International Journal of Business Management and Economic Review

Vol. 2, No. 03; 2019

ISSN: 2581-4664

\title{
RELATIONSHIPS OF BRAND IMAGE, CUSTOMER SATISFACTION AND BRAND LOYALTY: IN CASE OF TELECOMMUNICATION SECTOR
}

\author{
${ }^{1}$ Undrakhbuyan Altangerel and ${ }^{2}$ Tsend-Ayush Munkhnasan \\ ${ }^{1,2}$ Department of Business Administration, Da-Yeh University, Changhua, Taiwan
}

http://doi.org/10.35409/IJBMER.2019.3948

\begin{abstract}
In the 21st century, Customer life environment became better compared to ten years ago. Consequently, They are more likely to purchase brand products or services than common products or service such as smart phone, car, clothes, software to differentiate from others. Therefore, Companies actively develop their brand for extending the market size and creating sustainable business. Because well brand image leads to increase customer satisfaction and brand loyalty. Research study focused to investigate relationship among Brand Image, Customer Satisfaction and Brand Loyalty in telecommunication industry. About 70 percent of population in Mongolia actively use cellphone network and in the market, four companies such as Unitel, Mobicom, Gmobile and Skytel successfully provides the service to local country. Primary data will be collect from one hundred fifty customers who have 20-40 ages and SPSS software will be used in the analyzing process. From the result, the study will produce suggestion and conclusion which can help the companies to produce brand strategy and confirm relationship of independent and dependent variables according to literature review.
\end{abstract}

Keyword: Brand Image, Customer satisfaction, Brand Loyalty, Telecommunication Sector

\section{INTRODUCTION}

Brand Image is the impression in the mind of customers of a brand's total personality which may be imaginary or real shortcomings and qualities. Brand give different feelings for customers depending business industry type. For example, Brand image in bank may give trust and security feelings and Mining company's brand image is possible to reveal social responsibility. Rahi (2015) "The marketing strategy of current companies is measuring their performance by the brand image and it is a significant predictor of success". Thus, Companies develop their brand image depending the market segment and business purpose. Brand image directly relates to customer satisfaction and brand loyalty and these topics were popular studied among business researchers for forty years. Nam and Ekinci (2006) explained satisfaction like: "a person's feeling of pleasure or disappointment resulting from comparing a product's perceived performance (or outcome) about his or her expectations." In other words, it is the difference between product or service performance and consumer expectation. If a customer gets 


\section{International Journal of Business Management and Economic Review}

Vol. 2, No. 03; 2019

ISSN: 2581-4664

satisfaction while using particular brand product or service, they want to purchase again specific the brand, and it leads to creating brand loyalty. The primary purpose of marketing strategies is the maintenance and development of consumer brand loyalty to create robust competition in the market and increase service or product differentiation (Davcik and Sharma, 2015). Brand loyalty is a general marketing concept that gives attention for the development of long-term relationship among customer and brand. It is used to evaluate the performance of marketing strategies and brand equity ( Chi and Yeh, 2009 ). Aghekyan-Simonian\&Forsythe J (2012) identified, "Brand image has specified impact on loyalty intentions that is customer repurchase intentions." Mongolian telecommunication companies actively develop their brand image compared to other industries such as Finance, Mining, and Information Technology to increase customer satisfaction and create brand loyalty.

\section{LITERATURE REVIEW}

\subsection{Brand Image}

According to the American Marketing Association (2013), a brand is a term, design, name, symbol, or any other features that distinguish one company's product to the others. On his part, Salina (2012), pointed out that a brand image is the set of beliefs, ideas, and impression that a person holds regarding an object. Brand image has become progressively essential and useful brand of organization service differentiation, customer loyalty, and preferences, supporting for increasing market size. Brand management is not one of the business operations and becomes a source of competitiveness. Brand Image helps to increase the benefit of services and decrease purchase risks (Aghekyan-Simonian, 2015). It means that purchasers spend more time and energy to make the decision for certain services, and the main reasons are they don't have enough experience to ensure the most exceptional purchase. Under these situations, customers generally go via well-known brands, which helps to decrease the research efforts of consumers. Customers more like brand image, which can promise high-satisfaction, high-quality, and highvalue ( Huang, 2014 ).

\subsection{Customer Satisfaction}

Satisfaction is the consumers' fulfillment response. Angelova and Zekiri (2011) explained satisfaction like: "a person's feeling of pleasure or disappointment resulting from comparing a product's perceived performance (or outcome) about his or her expectations."According to Kandampully (2009) defined that satisfaction is an integral part of consumer's future purchasing as well as satisfied consumers delivery positive word of mouth of product or service to friends and relatives. Oh and Kim (2017) postulated that dissatisfactionis created when the expectation ishigher than the output of service performance and satisfactionis a case of service performance matching or surpassing on consumer expectations.However, the satisfaction cannot be the final goal of business, and it has to be a utilityfor improving the performance of the company (Hanif, 2010).

\subsection{Brand Loyalty}

The loyalty is defined by assurance or commitment to rebuy specific product or services in the future, regardless of competitor's efforts in the market.According to Sahin (2011), Brand loyalty is consumer selection to purchase a specific brand than other brands. Brand loyalty has several 


\section{International Journal of Business Management and Economic Review}

Vol. 2, No. 03; 2019

ISSN: 2581-4664

advantages for the company. First, Loyal customers more like to spread positive word-of-mouth, which helps to decrease marketing cost or attract new customers. Second, Loyal customers have high commitment to repurchase from a particular company, and they generate sustainability income for the company. Third, Loyal customers help marketers to define service price and produce a marketing plan. Zehir (2011) stated that Brand loyalty is considered to provide greater leverage to trade, condensed marketing costs, and building an augmented market share.

\subsection{Relationships among Brand Image, Customer satisfaction, and Brand loyalty}

Past researchers confirmed a positive association between brand image and satisfaction (Whyatt, 2011). Saleem (2014) stated that if the consumer's self-image is similar to a specific brand image, customer satisfaction will be high.Martenson (2007) defined that Brand Image has a positive relationship with customer satisfaction.Ogba (2009) mentioned that in the case of customer satisfaction surpass a specific level; the loyalty directly grows up.Most of the studies defined a positive relationship among the satisfaction and the loyalty and introduced that customer satisfaction is an essential factor or fundamental understanding of customer loyalty ( Raji, 2018).

Additionally, Previous researchers investigated the relationshipbetween Brand Image and Brand loyalty, and they found that Brand Image direct and indirect effects on Brand Loyalty. Because well brand image expresses high quality, high satisfaction, and low risks. Thus, Customers want to select famous brand service or product to reduce risks related to certain products. It means that well brand image positive influences on brand loyalty. Thus, following hypotheses proposed according to the literature review.

H1: Brand Image positively effect on Customer Satisfaction

H2: Brand Image has a positive relationship with Brand loyalty

H3: Customer Satisfaction has a positive relationship with Brand loyalty

\section{CONCEPTUAL FRAMEWORK AND DATA ANALYZING}

\subsection{Research framework}

According to the research purposes and literature review, the researcher constructed the framework of the study, which is presented in the figure below. The research framework has as the independent variable Bran image, as dependent variables: Customer Satisfaction and Brand Loyalty. 
Vol. 2, No. 03; 2019

ISSN: 2581-4664

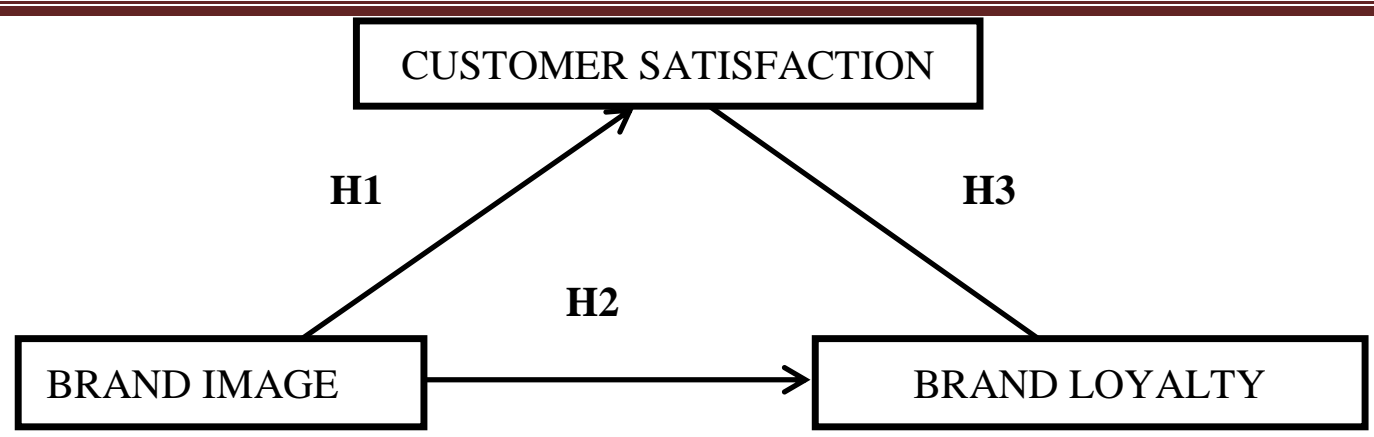

\subsection{Data sampling}

Research study collected primary data by social media channels such as Facebook, Twitter, and the total amount is two hundred. Questionnaire design has 40 questions related to demographic information, customer satisfaction, brand image, and brand loyalty. Collecting time interval continued from 5 March to 6 April and was distributed to social users who have 20-40 years old based on Facebook and Twitter ads.

\subsection{Demographic information}

Figure 3.1 shows the ages of respondents, and $69 \%$ of total participants are people who have 2637 ages. Also, Participants with 26-29 ages answered more actively than another group of ages and $30-33$ ages also have a higher percentage or $22 \%$.

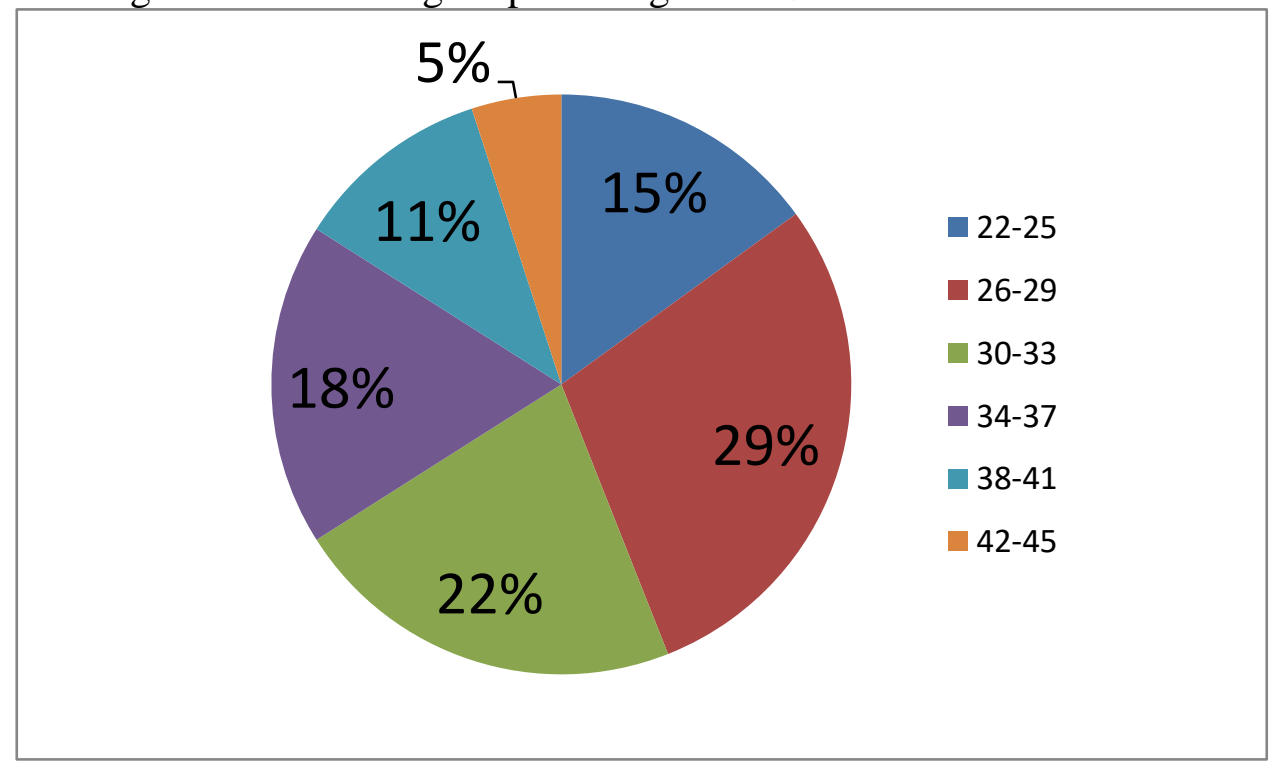

Figure 3.1 Ages of Participants

According to the below graphic, which displays marital status, 34 percent of participants were already married, and 66 percent were single. It shows single people actively participated in the survey. 
International Journal of Business Management and Economic Review

Vol. 2, No. 03; 2019

ISSN: 2581-4664

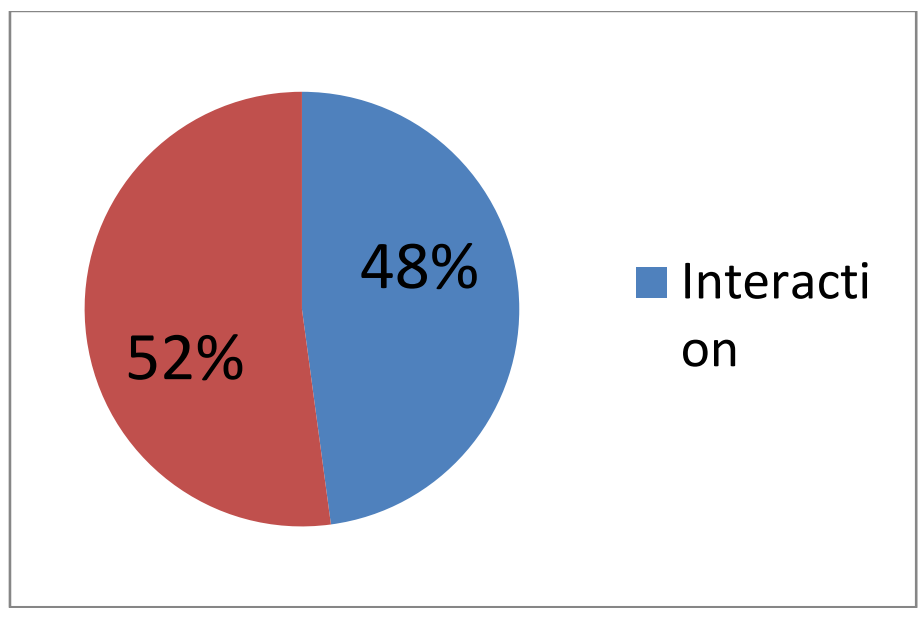

Figure 3.2 Marital Status

Below figure shows the respondent's education degree, and 48 percent of participants has a bachelor degree. Also, 24\% has a Master degree and people who have a master, and doctor degree more actively participated in the survey. 


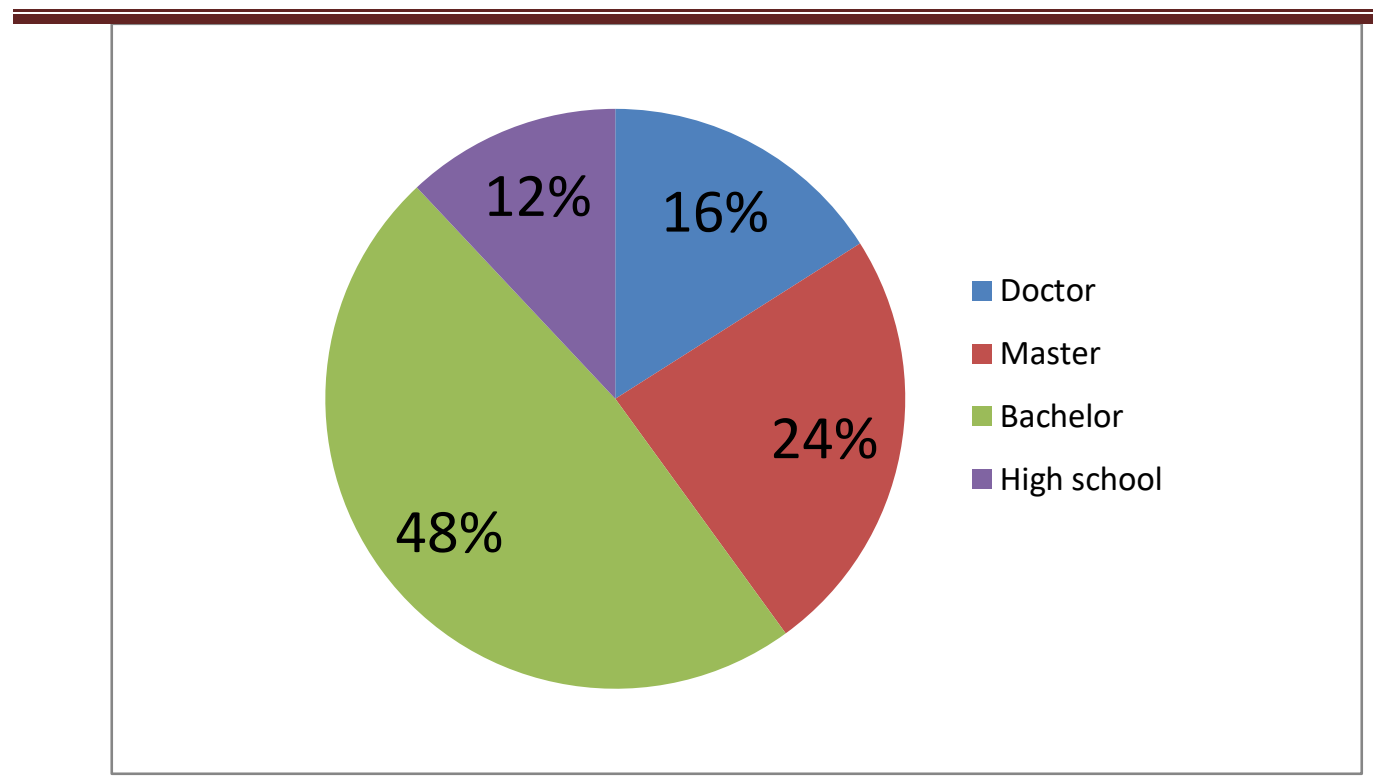

Figure 3.3 Education Level

Figure 7 shows income of respondents and $56 \%$ of total participants has 700,000-1,300,000 MNT income as well as $18 \%$ has 1,300,000-1,700,000MNT, 10\% has over 1700,000 MNT. Also, People who have the lowest income cover 5\% and their monthly income was lower than $400,000 \mathrm{MNT}$. From the graphic, We can conclude that consumers with higher income more use banking service.

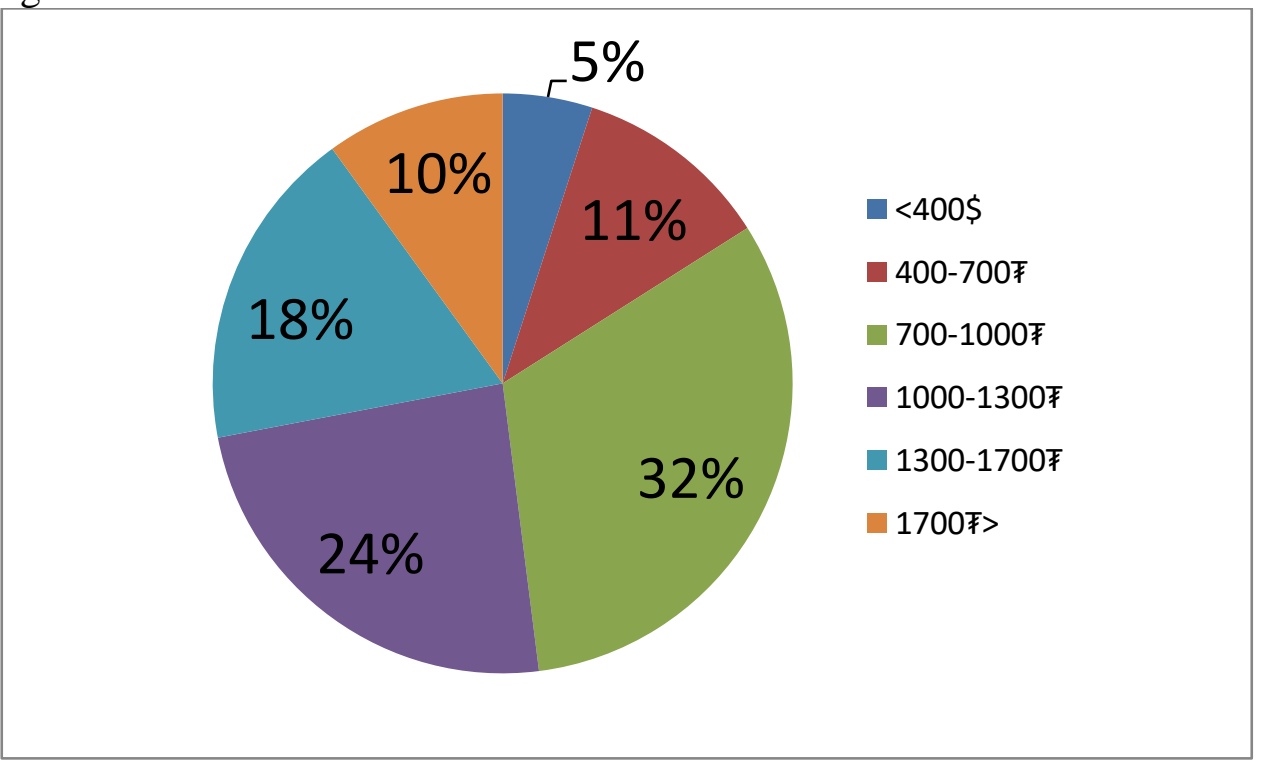

Figure 4.4 Income of Respondents

\subsection{Reliability analysis}

The reliability is implemented in various research areas, generally in social science. According to statistics, the analysis identifies the overall internal consistency of sampling. Otherwise, it is the level to which an assessment tool produces consistent and stable results. The reliability result is 


\section{International Journal of Business Management and Economic Review}

Vol. 2, No. 03; 2019

ISSN: 2581-4664

expressed by Cronbach's value, which locates among 0 and 1 . If the Cronbach's is near to 1 , it means the data has high internal consistency. Most of the researchers approve that Cronbach's alpha needs to be higher than 0.6 . If the value will match with the requirement, collected data is comfortable on analysis such as correlation, regression. Table 4.1 shows general Cronbach's value among all variables, and the value is equal with 0.842 or higher than 0.5 . It means all variables have high internal consistency or meets the requirement of analyzing procedures.

Table 3.1 Reliability Statistics among variables

\begin{tabular}{|c|l|}
\hline Cronbach's Alpha & N of Items \\
\hline .842 & 30 \\
\hline
\end{tabular}

Table 3.2 shows the reliability results related to independent and dependent variables such as customer satisfaction, brand image, and brand loyalty. The result values are higher than 0.6 , and it means that all variable s have high quality or internal consistency.

Table 3.2: Reliability Results of variables

\begin{tabular}{|l|c|}
\hline Variable & Cronbach's Alpha \\
\hline Customer satisfaction & 0.678 \\
\hline Brand Image & 0.871 \\
\hline Brand Loyalty & 0.797 \\
\hline
\end{tabular}

\subsection{Correlation Analysis}

The analysis defines the linear relationship between the independent and dependent variables. The analyzing result is expressed by $\mathrm{r}$ value or the Pearson Product Moment correlation coefficient. The value places in a limited range or between -1 and +1 . For example, if the value is equal with -0.4 , the variables have a negative relationship.Contrast, in the case of the value, is equal with 0.4 , the association is positive.

Table 3.3 Correlation Analysis

\begin{tabular}{|l|l|l|}
\hline & CS & BI \\
\hline BI & $.478^{* *}$ & \\
\hline BL & $.342^{*}$ & $.631^{*}$ \\
\hline
\end{tabular}

**. Correlation is significant at the 0.01 level (2-tailed)

Table 3.3 illustrates the linearrelationships of variables. According to the proposed hypothesis, following results outputted.

1. Customer satisfaction has a positive relationship with Brand Image ( $r=0.478, p<0.01$ )

2. Customer satisfaction has a positive relationship with Brand Loyalty $(r=0.342, p<0.05)$

3. Brand Image has positive relationship Brand Loyalty $(r=0.631, p<0.05)$

\subsection{Regression analysis}




\section{International Journal of Business Management and Economic Review}

Vol. 2, No. 03; 2019

ISSN: 2581-4664

Regression analysis defines the impact of a unit change in the independent variable on the dependent variable as well as find the best fitting line to determine the relationship of variables. R-squared value is essential in regression analysis, and the value defines how near the data placed to the fitted regression line. If the value equal with zero, it means that the model explains none of the variability of the response data around it means. Table 3.4 showsthe regression result related to the impact of Brand Image and Customer Satisfaction on Brand loyalty. According to the model summary, Adjusted R square equals 0.408, and it means that the model is explaining 40.8 percent of the distribution.

Table 3.4 Model Summary

\begin{tabular}{|l|l|l|l|l|}
\hline $\begin{array}{l}\text { Mode } \\
1\end{array}$ & $\mathrm{R}$ & $\mathrm{R}$ Square & $\begin{array}{l}\text { Adjusted } \\
\text { Square }\end{array}$ & $\begin{array}{l}\mathrm{R} \\
\begin{array}{l}\text { Std. Error of } \\
\text { the Estimate }\end{array}\end{array}$ \\
\hline 1 & $.456^{\mathrm{a}}$ & .414 & .408 & .2712 \\
\hline
\end{tabular}

Below Tableshows regression result of Brand Image, Customer satisfaction, and Brand Loyalty.

Table 3.5 Coefficients

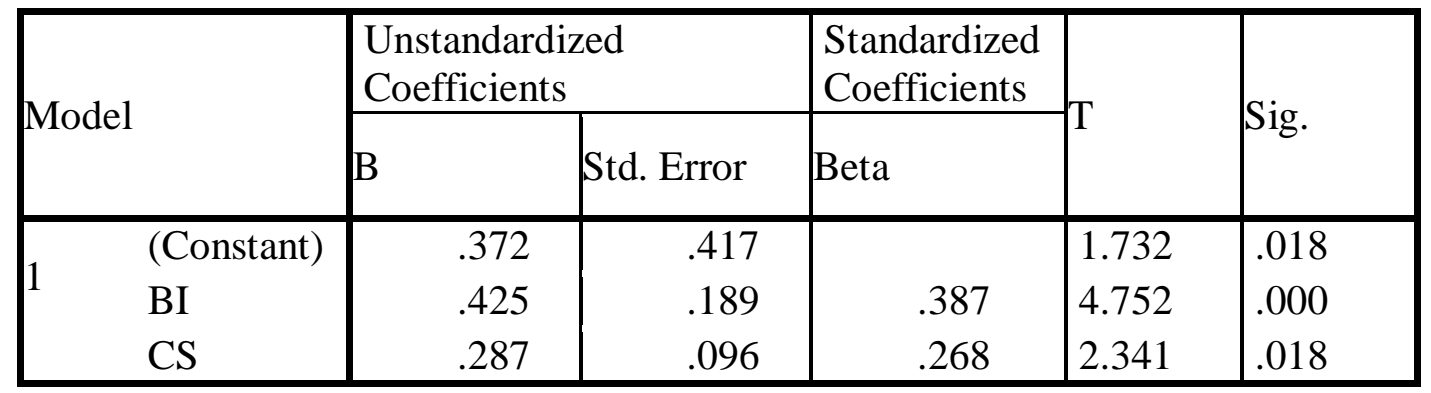

a. Dependent Variable: BL

According to the result, the Brand image has a positive relationship with brand loyalty ( $\mathrm{B}=0.387, \mathrm{p}<0.01)$ and Customer satisfaction has a positive relationship with brand loyalty ( $\mathrm{B}=0.287, \mathrm{p}<0.05$ ). Thus, our proposed hypotheses or $\mathrm{H} 2, \mathrm{H} 3$ were approved by the result. Final proposed hypotheses or $\mathrm{H} 2$ was analyzed, and the result illustrated in Table 3.6 and 3.7.

Table 3.6: Model Summary

\begin{tabular}{|r|l|l|l|l|}
\hline Model & $\mathrm{R}$ & R Square & $\begin{array}{l}\text { Adjusted R R } \\
\text { Square }\end{array}$ & $\begin{array}{l}\text { Std. The error } \\
\text { of the Estimate }\end{array}$ \\
\hline 1 & $.614^{\mathrm{a}}$ & .587 & .584 & .2172 \\
\hline
\end{tabular}

Table 3.7 Coefficients

\begin{tabular}{|l|l|l|l|l|}
\hline \multirow{3}{*}{ Model } & $\begin{array}{l}\text { Unstandardized } \\
\text { Coefficients }\end{array}$ & $\begin{array}{l}\text { Standardized } \\
\text { Coefficients }\end{array}$ & t & \multirow{2}{*}{ Sig. } \\
\cline { 2 - 5 } & B & Std. Error & Beta & \\
\hline
\end{tabular}




\section{International Journal of Business Management and Economic Review}

Vol. 2, No. 03; 2019

ISSN: 2581-4664

\begin{tabular}{|ll|l|l|l|l|l|}
\hline \hline 1 & (Constant) & .418 & .242 & & 2.784 & .001 \\
& BI & .569 & .184 & .454 & 1.847 & .000 \\
\hline
\end{tabular}

a. Dependent Variable: CS

According to table 3.6 and 3.7, Adjusted R square is 0.584 , and it means that the model is expressing 58.4 percent of the distribution. Additionally, Brand Image has a positive relationship with customer satisfaction ( $\mathrm{B}=0.454, \mathrm{p}<0.01$ ), and the result approved hypothesis 1 .

\section{CONCLUSION}

Mongolian telecommunication sector has rapidly developed since 1990, and the operator companies are actively competing by brand image to expand the market size. Brand Image is the perception of your product or brand by consumers, and previous researchers approved brand image leads to improve customer satisfaction and brand loyalty. Well, brand image helpsthecompany to save marketing cost, improve profit, and keep long-term business sustainability. The research study focused on investigatingthe relationship among Brand Image, Customer satisfaction, Brand loyalty of customers who use telecommunication services, and the data was gathered from 200 customers. According to data analyzing result, the independent and dependent variables have positive relationships with each other. It means that well brand image of the operator company positive effect on customer satisfaction and loyalty, and customer satisfaction directly positive effect on brand loyalty. Therefore, Mongolian telecommunication companies actively implement a broader marketing strategy of brand development to make differentiation from competitors and to increase loyalty customer number. Additionally, the result showed that telecommunication customers give more importance company brand image, and they want to use product or service with a high brand image to reduce uncertainty situation related to service usage.

\section{REFERENCES}

1. Severi, E., \& Ling, K. C. (2013). The mediating effects of brand association, brand loyalty, brand image and perceived quality on brand equity. Asian Social Science, 9(3), 125.

2. Rahi, S. (2015). Moderating role of brand image with relation to internet banking and customer loyalty: a case of branchless banking. The Journal of Internet Banking and Commerce, 20(3).

3. Nam, J., Ekinci, Y., \&Whyatt, G. (2011). Brand equity, brand loyalty and consumer satisfaction. Annals of tourism Research, 38(3), 1009-1030.

4. Davcik, N. S., \& Sharma, P. (2015). Impact of product differentiation, marketing investments and brand equity on pricing strategies: A brand level investigation. European Journal of Marketing, 49(5/6), 760-781.

5. Chi, H. K., Yeh, H. R., \& Yang, Y. T. (2009). The impact of brand awareness on consumer purchase intention: The mediating effect of perceived quality and brand loyalty. The journal of international management studies, 4(1), 135-144.

6. Aghekyan-Simonian, M., Forsythe, S., Kwon, W. S., \&Chattaraman, V. (2012). The role of product brand image and online store image on perceived risks and online purchase intentions for apparel. Journal of Retailing and Consumer Services, 19(3), 325-331. 


\section{International Journal of Business Management and Economic Review}

Vol. 2, No. 03; 2019

ISSN: 2581-4664

7. Salinas, E. M., \& Pérez, J. M. P. (2009). Modeling the brand extensions' influence on brand image. Journal of Business Research, 62(1), 50-60.

8. Aghekyan-Simonian, M., Forsythe, S., Kwon, W. S., \&Chattaraman, V. (2012). The role of product brand image and online store image on perceived risks and online purchase intentions for apparel. Journal of Retailing and Consumer Services, 19(3), 325-331.

9. Huang, R., \&Sarigöllï, E. (2014). How brand awareness relates to market outcome, brand equity, and the marketing mix. In Fashion Branding and Consumer Behaviors (pp. 113-132). Springer, New York, NY.

10. Angelova, B., \&Zekiri, J. (2011). Measuring customer satisfaction with service quality using American Customer Satisfaction Model (ACSI Model). International Journal of Academic Research in Business and Social Sciences, 1(3), 232.

11. Hu, H. H., Kandampully, J., \&Juwaheer, T. D. (2009). Relationships and impacts of service quality, perceived value, customer satisfaction, and image: an empirical study. The service industries journal, 29(2), 111-125.

12. Oh, H., \& Kim, K. (2017). Customer satisfaction, service quality, and customer value: years 2000-2015. International Journal of Contemporary Hospitality Management, 29(1), 2-29.

13. Hanif, M., Hafeez, S., \& Riaz, A. (2010). Factors affecting customer satisfaction. International Research Journal of Finance and Economics, 60(1), 44-52.

14. Sahin, A., Zehir, C., \&Kitapçı, H. (2011). The effects of brand experiences, trust and satisfaction on building brand loyalty; an empirical research on global brands. ProcediaSocial and Behavioral Sciences, 24, 1288-1301.

15. Zehir, C., Şahin, A., Kitapçı, H., \&Özşahin, M. (2011). The effects of brand communication and service quality in building brand loyalty through brand trust; the empirical research on global brands. Procedia-Social and Behavioral Sciences, 24, 12181231.

16. Nam, J., Ekinci, Y., \&Whyatt, G. (2011). Brand equity, brand loyalty and consumer satisfaction. Annals of tourism Research, 38(3), 1009-1030

17. Saleem, H., \& Raja, N. S. (2014). The impact of service quality on customer satisfaction, customer loyalty and brand image: Evidence from hotel industry of Pakistan. Middle-East Journal of Scientific Research, 19(5), 706-711.

18. Martenson, R. (2007). Corporate brand image, satisfaction and store loyalty: A study of the store as a brand, store brands and manufacturer brands. International Journal of Retail \& Distribution Management, 35(7), 544-555.

19. Ogba, I. E., \& Tan, Z. (2009). Exploring the impact of brand image on customer loyalty and commitment in China. Journal of Technology Management in China, 4(2), 132-144

20. Raji, R. A., Mohd Rashid, S., \&Mohd Ishak, S. (2018). Consumer-based brand equity (CBBE) and the role of social media communications: Qualitative findings from the Malaysian automotive industry. Journal of Marketing Communications, 1-24 